90 Informal Logic

\title{
Collaborative Learning: Higher Education, Interdependence, and the Authority of Knowledge
}

\section{KENNETHBRUFFEE}

The Johns Hopkins University Press: Baltimore, Maryland, 1993. Pp.240, including index, glossary, and endnotes.

ISBN 0-8018-4642-0. US \$29.95.

Reviewed by Bennett A. Rafoth

In the late 1950's M.L.J. Abercrombie, a London medical researcher, tried a new approach for training medical students in the practice of diagnosis. Instead of requiring each student to diagnose patients on his or her own, Abercrombie told the group to examine the patient together and arrive at a decision by consensus. The result of this collaborative approach was better medical judgment acquired faster. Abercrombie believed the success stemmed from the challenges students posed to one another's beliefs, minimizing decisions based upon bias or prejudice.

For Kenneth Bruffee, a leader in the collaborative learning movement in undergraduate liberal studies (especially English), Abercrombie's research provides the perfect parallel to teaching writing. He writes:

To say therefore that, in writing a medical diagnosis, writing decisions and medical decisions are one in the same and that what the diagnostician writes is what the diagnosis is, is to say that when we think about which word to use next, or its proper form, or how to begin the next paragraph, we are talking to our (socially constructed) selves, and to (socially constructed) others, about the (socially constructed) subject about which we are making a (socially constructed) judgment (p. 57).

Comparing a diagnosis to "how to begin the next paragraph" is surprising, to say the least. Is learning to diagnose really equivalent to learning to write an essay? It is not an idle question, for the claims in this book go beyond even writing to learning in all disciplines by all students under all circumstances. The author notes that both diagnosis and writing are construed in words and that both are validated against the standard-bearers of their communities-senior physicians or English professors. For Bruffee, all learning is linguistic.

Perhaps what makes this book most interesting is the author's unflagging adherence to the social constructivist principles he sets forth in the opening chapters. Bruffee leaves little room for qualifying statements and none at all for the few but poignant criticisms made against collaborative learning in his own field. Collaborative Learning provides at least half a dozen chapters on the theoretical basis for what the author believes to be an unshakable revolution overtaking American classrooms. His ideas draw from Kuhn, Rorty, Dewey, and Latour, all for whom the notion of authority in education is linked to structures of power and prestige.

For those who teach critical thinking/informal logic, this book describes two forces every teacher of undergraduates must reckon with - the teacher's yearning to 
push students beyond past experience and conventional thought, and the student's need for peer approval and group membership. The author believes that peer relationships, particularly conversations with more knowledgeable classmates, confront the limits of past experience and lead students to new critical perspectives. He devotes one chapter to practical suggestions for how to bring about these conversations in the classroom, including tips for asking questions that have more than one answer, asking controversial questions, and asking students to analyze short passages concretely. While Bruffee's main interest in writing this book is theoretical, readers who want classroom applications will find them.

Collaborative Learning may find its most sympathetic readers among teachers of composition and literature. For over twenty years, Bruffee has led the way in making group work pedagogically popular and intellectually interesting. Peer tutoring, peer editing of essays, collaborative writing assignments, and consensus group interpretations of literary works owe their widespread adoption at the college level in part to Bruffee's advocacy. For this audience, the book provides a rationale for using collaborative methods in the classroom. On the other hand, there is little by way of close scrutiny of conflict resolution within groups, reasoning operations, or taking others' perspectives-outcomes touted by collaborative learning proponents. There is substantial empirical and theoretical research in these areas in cognitive and social psychology, as well as in his own field of composition studies, but Bruffee makes little mention of it. He takes pains to put distance between the non-foundational social constructivism he espouses and the foundational cognitive paradigm he rejects.

Bruffee believes that collaborative learning is destined to transform society's beliefs about the grounding of knowledge. He insists that collaborative learning is different from reform movements of the sixties, which failed because of their foundational assumptions about the nature and authority of knowledge. Yet he seems unconcerned that promising too much and undermining other pedagogies may be what doomed past movements and may even rob collaborative learning of its worth. When, for example, does the author's vision for the classroom of the future allow for demonstration, modeling, or direct instruction? When do students have the freedom to declare that they prefer to listen rather than talk or to work alone rather than together?

Collaborative Learning is about how students in a democratic society reacculturate themselves into the academic communities they want to join. The irony of this book is that the author's strict adherence to the collaborative monolith defines what every student's education is about and therefore what every teacher's pedagogy ought to be. One wonders how many other varieties of teaching and learning Abercrombie's medical students had experienced in their decades of schooling before they even had something medical to say to one another.

BENNETT RAFOTH

ENGLISH DEPARTMENT

INDIANA UNIVERSITY OF PENNSYLVANIA

INDIANA, PA 15705-1094

USA 